\title{
PENGARUH PENERAPAN STRATEGI GENIUS LEARNING TERHADAP KEMAMPUAN BERPIKIR KREATIF PESERTA DIDIK KELAS X IPA SMA
}

\author{
Bepi Patrira $^{1 *}$, Ajo Dian Yusandika ${ }^{1}$, Henny Wulandary ${ }^{2}$ \\ ${ }^{1}$ Prodi Pendidikan Fisika, Universitas Islam Negeri Raden Intan Lampung \\ ${ }^{2}$ Prodi Pendidikan Bahasa Arab, Universitas Islam Negeri Raden Intan Lampung \\ * Corresponden author: bepipatrira0506@gmail.com
}

Article History:

Received: mei 12, 2020

Revised: juni 17, 2020

Accepted: oktober 11, 2020

Published: desember 18, 2020

Keywords: Genius Learning Strategies, Creative Thinking, Straight-Motion

\begin{abstract}
The teacher has never applied and measured the creative thinking skills of class $X$ students. However, after the researchers made observations on the creative thinking skills of students in this school, the results were in the low category. The purpose of this study was to see the effect of the application of the genius learning strategy on the creative thinking skills of students of class $X$ majoring in science in physics learning on the subject of linear motion at SMAN 1 Pulaupanggung. The research method used in this research was quasy experiment. The design used in this study was the nonequivalent control group design. A total of 64 students of class X SMAN 1 Pulaupanggung consisting of 2 classes were selected as the research sample using purposive sampling technique. The data collection technique used was a test instrument in the form of 9 essay questions. Then, the data were processed using the normality test and homogeneity test which were then analyzed using the average difference test (t-test). The application of the genius learning strategy has an effect on improving the creative thinking skills of students on the subject of straight motion at SMAN 1 Pulaupanggung.
\end{abstract}

\begin{abstract}
Abstrak: Pendidik belum pernah menerapkan dan mengukur kemampuan berpikir kreatif secara langsung terhadap peserta didik kelas X. Tetapi setelah peneliti melakuakn observasi kemampuan berpikir kreatif terhadap peserta didik termasuk rendah. Tujuan dari penelitian ini adalah untuk mengetahui apakah terdapat pengaruh antara penerapan strategi genius learning dan tanpa menerapkan strategi genius learning terhadap kemampuan berpikir kreatif Peserta didik kelas X IPA SMA pembelajaran fisika pada pokok bahasan gerak lurus di SMAN 1 Pulaupanggung. Metode penelitian yang digunakan dalam penelitian ini yaitu quasy eksperiment. Desain yang digunakan dalam penelitian ini adalah nonequivalent control group design. Pengambilan sampel pada penelitian ini menggunakan teknik purposive sampling populasi dalam penelitian ini adalah peserta didik kelas X SMAN 1 Pulaupanggung, yang berjumlah 64 orang yang terdiri dari 2 kelas. Teknik pengumpulan data digunakan tes, berupa soal essay sebanyak 9 butir soal. Kemudian data diolah dengan uji normalitas dan uji homogenitas yang kemudian dianalisis menggunkan uji perbedaan (t-tes). Penerapan strategi genius learning berpengaruh dalam meningkatkan kemampuan berpikir kreatif peserta didik pada pokok bahasan gerak lurus di SMAN 1 Pulaupanggung.
\end{abstract}




\section{PENDAHULUAN}

Teknologi pendidikan berkembang sesuai dengan kebutuhan belajar. Penerapan teknologi dalam pendidikan pembelajaran diharapkan dapat terciptanya belajar yang lebih efektif, efisien dan lebih cepat (Yuberti, 2015) Permendikbud No. 59, 2014:900, bahwa fisika merupakan proses dalam memperoleh informasi secara empiris (empirical method), informasi yang ada didapatkan melalui tatanan yang sistematis juga logis dan informasi yang dihasilkan dapat dipercaya dan valid karena merupakan gabungan proses berpikir kritis (Maghfiroh, Djoko, \& Supriadi, 2017), hal ini juga sejalan dengan tujuan dari pendidikan. Tujuan pendidikan menghantarkan anak untuk mencapai pemahaman yang dapat mereka ungkapkan melalui lisan, tulisan, atau kerangka berpikir yang positif. Pemahaman adalah landasan untuk mendapatkan kemampuan memecahkan masalah, berpikir kreatif, dan berpikir kritis (Alatas, 2014). Selaian itu, diperlukan kemampuan salah satunya mengelola dan memilih informasi dengan pemikiran yang kreatif yang bersumber dari ilmu pengetahuan itu sendiri (Febrina Sari, Niniwati, \& Zuzano, 2017)

Pembelajaran fisika atau fisika itu sendiri merupakan pengetahuan yang mendasar yang dibutuhkan untuk kemajuan teknologi dengan cara mengintegrasikannya dengan salah satunya yaitu pengembangan kreativitas. Oleh karna itu peserta didik dituntut untuk lebih kreatif dan aktif terlibat (Istiyono, Bram Dwandaru, \& Rahayu, 2018). Pada pembelajaran fisika, peserta didik dituntut untuk mampu menerapkan didalam kehidupannya sehari-hari. Peserta didik juga didorong untuk memiliki memampuan berpikir kreatif dalam mengupayakan pembahruan ide-ide yang sudah ada maupun yang memang belum ada. Kemampuan berpikir kreatif di dalam pembelajaran fisika sangat diperlukan untuk hasil belajar peserta didik itu sendiri.

Hakikatnya setiap peserta didik memiliki kemampuan untuk berpikir kemampuan berpikir inilah yang menjadikan manusia sebagai makhluk ciptaan Allah yang paling mulia diatara makhluk-makhluk lainnya (Hendrayana, 2017). Oleh sebab itu, jika berpikir peserta didik dilatihkan dalam proses pembelajaran diharapkan hasil belajar siswa akan meningkat.

Berdasarkan hasil wawancara dengan tenaga pendidik mata pelajaran IPA Fisika di SMA N 1 Pulaupanggung Tanggamus menyatakan bahwa kemampuan berpikir kreatif peserta didik masih rendah. Pendidik mengatakan bahwa kemampuan berpikir kreatif peserta didik memang rendah hal ini dikarenakan pendidik tidak pernah mengukur dan melatih kemampuan berpikir kreatif secara khusus. Tetapi dapat dilihat dari hasil ulangan harian dan keseharian peserta didik. Hal ini diperkuat dengan fakta yang ada di lapangan, Berdasarkan hasil observasi yang telah dilakukan, strategi pembelajaran yang digunakan untuk menumbuhkan kemampuan berpikir kreatif peserta didik kurang diperhatikan, dapat dilihat saat peneliti melakukan observasi. Saat proses pembelajaran sedang dilaksanakan suasana kelas terlihat kurang kondusif, hal ini ditandai dengan ketika pendidik sedang memberikan meteri kepada peserta didik, sedikit sekali yang memperhatikan dan ini berlanjut ketika pendidik berikan pertanyaan hanya sedikit peserta didik yang menanggapi, dikarenakan peserta didik asik dengan kegiatan masing-masing mengobrol dikelas. 
Dilihat dari permasalahan di atas, untuk meningkatkan kemampuan berpikir kreatif pendidik harus menggunakan metode yang sesuai. Dari berbagai strategi pembelajaran yang ada, peneliti mencoba menerapkan strategi pembelajaran Genius learning sebagai upaya menumbuh kemampuan berpikir kreatif peserta didik.

Dengan menerapkan Dengan menerapkan strategi genius learning memposisikan peserta didik sebagai pusat dari proses pembelajaran atau sebagai subjek pendidikan. Proses belajar yang dilakukan peserta didik akan lebih rileks, sehingga peserta didik lebih berminat untuk belajar dan peserta didik merasa lebih nyaman dalam mengikuti proses belajar. Selain itu, pembelajaran dengan menerapkan strategi genius learning dapat membantu peserta didik untuk mengerti kekuatan dan kelebihan mereka yang sesuai dengan gaya belajar mereka masing-masing. Yang diharapkan yakni anak didik yang aktif, kreatif dan mandiri. Sehingga akan menciptakan suasan belajar yang efektif dan efisien (Nilawati, 2016). Kelebihan metode genius learning di antaranya peserta didik dapat mendapatkan kerangka pikiran yang benar (relaks, percaya diri dan siap untuk belajar), memperoleh informasi dalam cara-cara yang paling sesuai, menyelidiki makna, implikasi dan arti persoalannya, mampu memicu memori ketika membutuhkannya, dan dapat memperoleh makna suatu topik secara cepat dengan menggunakan peta konsep (Naimah \& A, 2017). Terdapat delapan langkah penerapan Genius Learning dalam proses pembelajaran, secara rinci kedelapan tahap dijelaskan sebagai berikut: 1) suasana kondusif, 2) hubungkan, 3) Gambaran besar, 4) Tetapkan tujuan, 5) Pemasukan informasi, 6) Aktivasi, 7) Demonstrasi dan 8) Ulangi (Anita, 2016)
Beberapa penelitian yang menerapkan strategi genius learning yang dapat meningkatkan kemampuan berpikir kreatif diantaranya yaitu; Efektivitas Model Pembelajaran Sinektiks (Mawarni \& Angraini, 2015); Pembelajaran Project Based Learning (PjBL) (W. P. Sari, Hidayat, \& Kusairi, 2018); Pembelajaran Creative Problem Solving (CPS) (Budiarti, 2016); Pembelajaran Pendidikan Teknologi Dasar (PDT) (I. M. Sari, Sumiati, \& Siahaan, 2013); Contextual Teaching And Learning (CTL)(Winarti, 2015) ; Analisis Kebutuhan Bahan Ajar Matematika (Pratiwi, Matematika, \& Dahlan, 2018)

Perbedaan penelitian ini dengan penelitian-penelitian sebelumnya adalah, pada penelitian ini untuk meneliti pengaruh penerapan strategi genius learning dan tanpa menerapkan strategi genius learning terhadap kemampuan berpikir kreatif Peserta didik kelas X IPA SMA.

\section{METODE PENELITIAN}

Metode penelitian yang digunakan adalah metode quasy eksperimen atau eksperimen semu dengan desain Nonequivalent Control Group Desaign. Populasi dalam penelitian ini adalah seluruh peserta didik kelas X SMA N 1 Pulaupanggung, dan sampel yang dipilih dengan teknik Purposive Sampling adalah kelas X2 MIPA 1 sebagai kelas eksperimen dan kelas $\mathrm{X}$ MIPA 1 sebagai kelas kontrol. Penelitian ini terdiri dari dua variabel yaitu variabel bebas dan variabel terikat, variabel bebas pada penelitian ini adalah strategi genius learning sedangkan variabel terikat adalah kemampuan berpikir kreatif.

Teknik pengumpulan data dalam penelitian ini menggunakan tes essay untuk mengukur kemampuan berpikir kreatif, diberikan sebelum dan sesudah 
diterapkan perlakuan pembelajaran, serta lembar observasi keterlaksanaan strategi genius learning.

Sebelum instrumen tes kemampuan berpikir kreatif diberikan kepada kelas eksperimen dan kontrol, terlebih dahulu dilakukan pengujian instrument dengan melakukan uji validitas, uji tingkat kesukaran, uji daya beda, dan uji reliabilitas. Uji hipotesis penelitian ini menggunakan uji-t. Dalam penelitian ini prasyarat yang harus dipenuhi terlebih dahulu, sebelum dilakukan uji prasyarat analisis yaitu, uji normalitas dan uji homogenitas.

\section{HASIL DAN PEMBAHASAN}

\section{A. Uji Prasyarat}

Uji materi prasyarat meliputi uji normalitas dan uji homogenitas. Data yang digunakan untuk uji homogenitas dalam penelitian ini adalah data yang diperoleh dari nilai test awal yang diberikan pada kelas X MIPA 1 dan X MIPA 2 yang telah terdistribusi normal. Hasil analisis uji normalitas dapat dilihat pada Tabel 1 sebagai berikut:

Tabel 1 Hasil uji normalitas posttest kelas eksperimen dan kontrol

\begin{tabular}{|c|c|c|c|c|}
\hline \multirow{2}{*}{ Statistik } & \multicolumn{2}{|c|}{ Eksperimen } & \multicolumn{2}{c|}{ Kontrol } \\
\cline { 2 - 5 } & Pretest & Posttest & Pretest & $\begin{array}{c}\text { Posttes } \\
t\end{array}$ \\
\hline L $_{\text {hitung }}$ & 0,142 & 0,119 & 0,156 & 0,137 \\
\hline $\mathrm{L}_{\text {tabel }}$ & 0,164 & 0,164 & 0,177 & 0,177 \\
\hline Kesimpulan & \multicolumn{2}{|c|}{ Normal } & \multicolumn{2}{c|}{ Normal } \\
\hline
\end{tabular}

Berdasarkan tabel 1 diketahui bahwa hasil uji normalitas kemampuan berpikir kreatif dengan tarif signifikn 0.05 untuk kelas eksperimen dengan Lhitung pretest 0,142 dan $\mathrm{L}_{\text {hitung }}$ Posttest 0,119 kurang dari $\mathrm{L}_{\text {tabel }} 1.64$ karena $\mathrm{L}_{\text {hitung }} \leq \mathrm{L}_{\text {tabel }}$ maka sampel tersebut terdistribusi normal, kemudian untuk kelas kontrol dengan $L_{\text {hitung }}$ pretest 0,156 dan Lhitung Posttest 0,137 kurang dari $\mathrm{L}_{\text {tabel }} 0,177$ karena $\mathrm{L}_{\text {hitung }} \leq \mathrm{L}_{\text {tabel }}$ maka sampel tersebut terdistribusi normal.

Selanjutnya data diuji variansnya dan diuji kesamaan rata-rata dua pihak untuk mengetahui kehomogenan kedua kelas. Uji varians dilakukan sebagai syarat dari uji homogenitas, karena data yang diuji harus mempunyai varians yang sama. Hasil analisis uji homogenitas dapat dilihat pada Tabel 2 sebagai berikut:

Tabel 2 Hasil Uji Homogenitas Kelas Eksperimen dan Kelas Kontrol

\begin{tabular}{|c|c|c|}
\hline Statistik & Pretest & Posttest \\
\hline $\mathrm{F}_{\text {hitung }}$ & 1,66 & 0,63 \\
\hline $\mathrm{F}_{\text {tabel }}$ & 1,81 & 1,81 \\
\hline Kesimpulan & Homogen & Homogen \\
\hline
\end{tabular}

Berdasarkan tabel tersebut diketahui bahwa hasil Pretest kelas eksperimen dan kelas kontrol didapet F hitung sebesar 1.66 dan hasil Posttest diperoleh Fhitung sebesar 0,63, sedangkan $\mathrm{F}_{\text {tabel }}$ sebesar 1.81, melihat hasil data tersebut diperoleh $F_{\text {hitung }} \leq F_{\text {tabel }}$, dengan demikian kedua sampel tersebut homogen. Dapat disimpulkan bahwa variabel $\mathrm{X}$ (Strategi Genius Learning) berpengaruh terhadap kedua variabel Y (kemampuan berpikir kreatif). 


\section{B. Uji Hipotesis}

Data yang digunakan untuk uji hipotesis dalam penelitian ini adalah selisih antara nilai posttest dan pretest. Nilai rata-rata kemampuan berpikir kreatif pretest dan postest di tunjukkan pada tabel 3 berikut:

Tabel 3 Nilai Rata-rata Kemampuan Berpikir Kreatif Pretest dan Postest

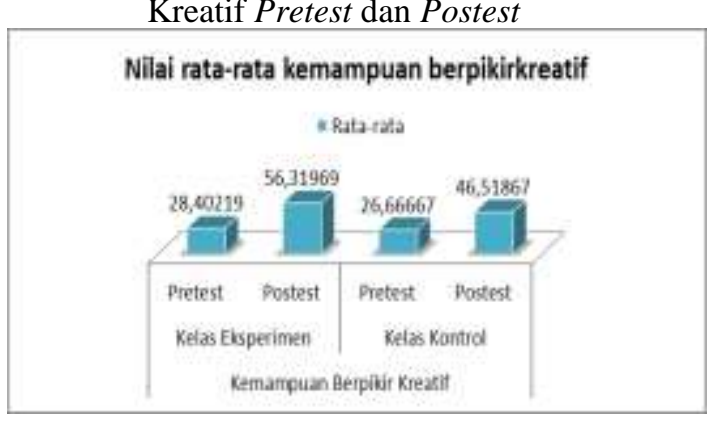

Dari grafik diatas menunjukkan bahwa nilai rata-rata kemampuan berpikir kreatif peserta didik sebelum diberikan perlakuan (pretest) dan sesudah diberikan perlakuan (posttest), pada kemampuan berpikir kreatif kelas eksperimen memperoleh nilai rata-rata pretest sebesar 28,4, dan posttest sebesar 56,3, sedangkan pada kelas kontrol nilai rata-rata pemahaman konsep yang diperoleh sebesar 26,6 untuk pretest dan 46,5 untuk posttest. Berdasarkan perolehan nilai tersebut dapat disimpulkan bahwa kemampuan berpikir kreatif peserta didik mengalami peningkatan baik pada kelas eksperimen maupun kelas kontrol.

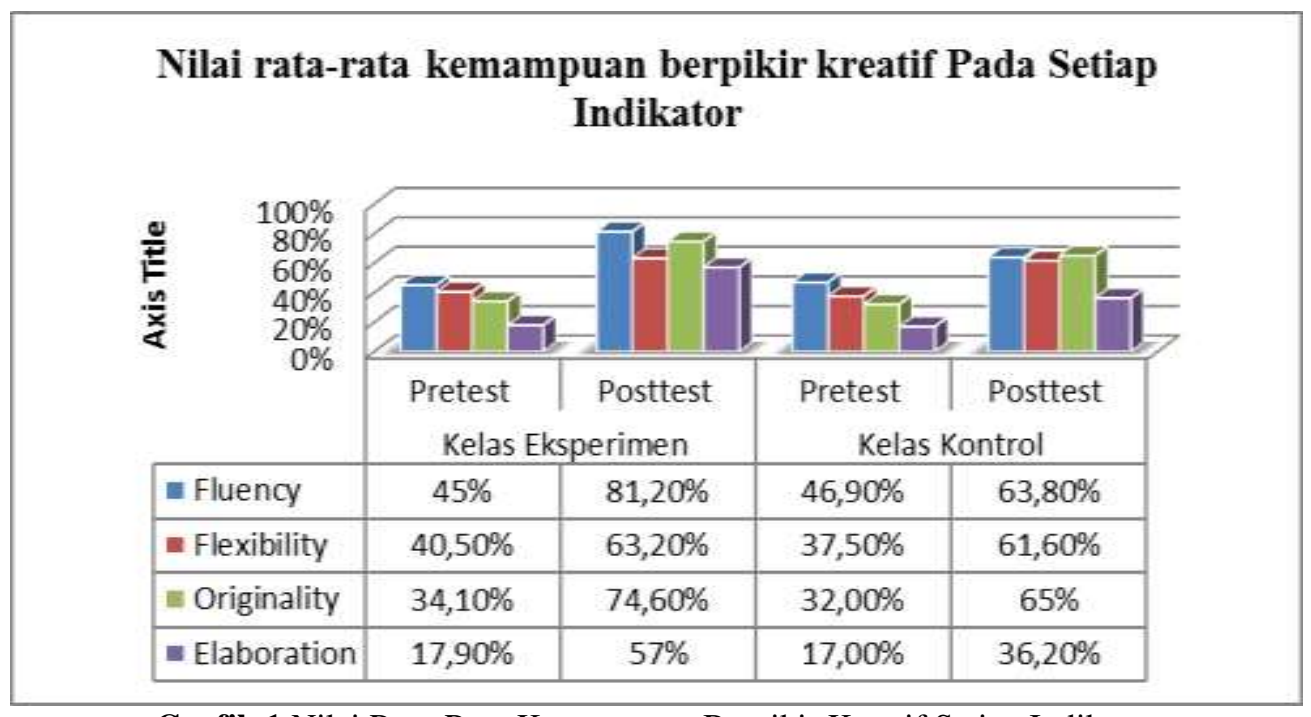

Grafik 1 Nilai Rata-Rata Kemampuan Berpikir Kreatif Setiap Indikator

Grafik 1 menunjukkan nilai ratarata nilai kemampuan berpikir kreatif peserta didik pada setiap indikator memiliki nilai yang berbeda-beda pada setiap indikator. Keempat indikator kemampuan berpikir kreatif yaitu Fluency (berpikir lancar), Flexibility (berpikir luwes), Originality (mengelompokkan) dan Elaboration (merinci). Pada kelas eksperimen memiliki nilai rata-rata yang lebih tinggi dibandingkan dengan kelas kontrol. Dapat dilihat dari grafik diatas dari ketujuh indikator kemampuan berpikir kreatif nilai rata-rata tertinggi ada pada indikator Fluency pada kelas eksperimen dan indikator Originality pada kelas kontrol.

Data pretest diperoleh sebelum diadakan perlakuan kepada kedua kelas sampel. Data posttest diperoleh 
setelah diadakan perlakuan. Selisih nilai tersebut menunjukkan besarnya peningkatan hasil belajar siswa dengan dan tanpa penerapan strategi
Genius Learning. Hasil analisis uji hipotesis dapat dilihat pada Tabel 4 sebagai berikut:

Tabel 4 Hasil Uji Hipotesis Posttest Kelas Eksperimen dan Kelas Kontrol

\begin{tabular}{|l|l|c|}
\hline $\mathbf{T}_{\text {hitung }}$ & \multicolumn{1}{|c|}{$\mathbf{T}_{\text {tabel }}$} & Keputusan Uji-t \\
\hline 2,33 & 1,67 & $\mathrm{H}_{0}$ di tolak $\mathrm{H}_{1}$ diterima (terdapat pengaruh) \\
\hline
\end{tabular}

Berdasarkan tabel diatas, dapat diketahui bahwa $\mathrm{T}_{\text {tabel }}$ dengan taraf signifikan $\alpha=0,05$ pada kelas eksperimen diperoleh rata-rata 56,32 dengan varian sebesar 386,0 sedangkan pada kelas kontrol diperoleh rata-rata 46,52 dengan varian sebesar 153,2. Selanjutnya diperoleh $\quad \mathrm{T}_{\text {hitung }}>\mathrm{T}_{\text {tabel }} \quad$ yaitu 2,33>1,67 sehingga $\mathrm{H}_{0}$ ditolak $\mathrm{H}_{1}$ diterima dengan demikian terdapat pengaruh artinya strategi genius learning terhadap kemampuan berpikir kreatif peserta didik kelas $\mathrm{X}$ IPA SMA.

Tabel 5 Hasil Analisis Uji N-Gain Kemampuan Berpikir Kreatif

\begin{tabular}{|l|c|r|r|c|c|}
\hline \multicolumn{1}{|c|}{ Kelas } & N & \multicolumn{1}{c|}{$\begin{array}{c}\text { Rata-rata } \\
\text { Pretest }\end{array}$} & $\begin{array}{c}\text { Rata-rata } \\
\text { Posttest }\end{array}$ & $\begin{array}{c}\text { Rata-Rata } \\
\text { N-Gain }\end{array}$ & Kriteria \\
\hline Eksperimen & 32 & 28,40 & 56,32 & 0,44 & sedang \\
\hline Kontrol & 30 & 26,67 & 46,52 & 0,35 & sedang \\
\hline
\end{tabular}

Pada tabel 5 diketahui perbedaan nilai rata-rata $\mathrm{N}$-Gain kemampuan berpikir kreatif antara kelas eksperimen dan kelas kontrol. Pada kelas eksperimen nilai rata-rata $\mathrm{N}-$ Gain kemampuan berpikir kreatif peserta didik sebesar 0,44.
Sedangkan pada kelas kontrol diperoleh nilai rata-rata $\mathrm{N}$-Gain kemampuan berpikir kreatif peserta didik sebesar 0,36. Nilai rata-rata $\mathrm{N}$ Gain dari kedua kelas masuk dalam kriteria sedang.

Tabel 6 Hasil Uji Effect Size Kemampuan Berpikir Kreatif

\begin{tabular}{|c|c|c|c|}
\hline $\begin{array}{c}\text { Sd } \\
\text { Kelas Eksperimen }\end{array}$ & $\begin{array}{c}\text { Sd } \\
\text { Kelas Kontrol }\end{array}$ & Effect Size (d) & Kategori \\
\hline 27,62 & 26,22 & 0,32 & Sedang \\
\hline 55,79 & 46,44 & 0,32 & \\
\hline
\end{tabular}

Setelah dilakukan perhitungan effect size diperoleh nilai $d$ sebesar 0,32 . Nilai $d$ ini kemudian diinterpretasikan kedalam kategori effect size. Nilai $d=0,32$ dalam penelitian ini masuk dalam kategori sedang. Sehingga dapat disimpulkan bahwa pengaruh penerapan strategi genius learning efektif dalam meningkatkan kemampuan berpikir kreatif peserta didik.

\section{PEMBAHASAN}

Berdasarkan tabel diatas, dapat diketahui bahwa $\mathrm{T}_{\text {tabel }}$ dengan taraf signifikan $\alpha=0,05$ pada kelas eksperimen diperoleh rata-rata 56,32 dengan varian sebesar 386,0 
sedangkan pada kelas kontrol diperoleh rata-rata 46,52 dengan varian sebesar 153,2. Selanjutnya diperoleh $\quad \mathrm{T}_{\text {hitung }}>\mathrm{T}_{\text {tabel }} \quad$ yaitu 2,33>1,67 sehingga $\mathrm{H}_{0}$ ditolak $\mathrm{H}_{1}$ diterima dengan demikian terdapat pengaruh artinya strategi genius learning terhadap kemampuan berpikir kreatif peserta didik kelas $\mathrm{X}$ IPA SMA.

Juga dapat dilihat dari hasil pada saat diberikan pretes, pencapaian tes hasil belajar siswa pada materi pokok gerak lurus pada kelas eksperimen adalah 28,4 dan pada kelas kontrol 26,6, jadi kemampuan awal siswa pada kelas eksperimen dan kontrol adalah hampir sama. Kemudian dilakukan uji beda untuk nilai pretes dan diperoleh Fhitung $=1,66<$ Ftabel $=$ 1,88 maka disimpulkan bahwa kedua sampel memiliki varians yang homogen. Setelah dilakukan perlakuan yang berbeda diperoleh nilai rata-rata kemampuan berpikir kreatif untuk kelas eksperimen 56,3 sedangkan dikelas kontrol 46,5 Dari hasil postes kedua sampel tersebut diperoleh selisih sebesar 10 sehingga terdapat perbedaan pada kelas eksperimen dan kelas kontrol. Dimana kelas eksperimen lebih tinggi dari pada kelas kontrol.

Besarnya pengaruh penerapan strategi Genius Learning dalam pembelajaran fisika pada pokok bahasan gerak lurus di kelas X MIPA 2 (kelas eksperimen) dengan nilai tertinggi yaitu 88,8. Sedangkan besarnya pengaruh penggunaan pengajaran konvensional di kelas $\mathrm{X}$ MIPA 1 (kelas kontrol) yaitu 66,67. Dan nilai perindikator kemampuan berpkir kreatif peserta didik mengalami peningkatan yang sangat baik terutama pada indikator berpikir luwes di kelas eksperimen yang diajar dengan strategi Genius Learning memiliki nilai rata-rata $81,2 \%$. Sedangkan nilai perindikator kemampuan berpkir kreatif peserta didik di kelas kontrol yang diajar dengan metode konvensional nilainya yaitu rata-rata $65 \%$ pada indikator Originality. Berdasarkan analisa di atas dapat diketahui, bahwa kemampuan berpikir kreatif peserta didik pada kelas eksperimen yang diberikan perlakuan dengan menggunakan strategi Genius Learning mengalami peningkatan yang lebih baik daripada kelas kontrol yang menggunakan pengajaran konvensional. Hal ini disebabkan siswa kelas eksperimen melakukan pembelajaran dengan strategi Genius Learning. Strategi Genius Learning dapat membantu siswa mempelajari konsep fisika. Dengan menggunakan strategi ini pembelajaran tidak terpusat pada guru. Siswa dituntut untuk lebih aktif dalam kegiatan belajar mengajar.

Nilai hasil kemampuan berpikir kreatif peserta didik kelas eksperimen dengan strategi Genius Learning sangat dipengaruhi oleh kegiatan-kegiatan yang diberikan kepada siswa yaitu, dengan memberikan perlakuan awal seperti memberi tugas, membuat kesimpulan, dan diskusi dalam kelompok. Dengan tugas peserta didik lebih termotivasi untuk melakukan diskusi dan mengerjakan soal-soal yang diberikan guru kepada setiap kelompok peserta didik. Dengan demonstrasi peserta didik lebih mudah mengingat pelajaran karena setiap peserta didik diberi kesempatan untuk 
mendemonstrasikan pelajaran yang dipelajarinya baik perkelompok maupun perindividu. Dengan lingkaran donat siswa lebih mudah mengingat pelajaran yang telah diketahui sebelumnya dan pelajaran yang diketahuinya setelah belajar dikelas, siswa juga dapat membandingkan bagaimana pengetahuan awalnya dan pengetahuan setelah belajar dikelas.

\section{SIMPULAN}

Nilai hasil kemampuan berpikir kreatif peserta didik pokok bahasan gerak lurus berdasarkan hasil perhitungan uji $t$ dengan taraf signifikan $\alpha=0,05$ pada kelas eksperimen diperoleh rata-rata 56,32 dengan varian sebesar 386,0 sedangkan pada kelas kontrol diperoleh rata-rata 46,52 dengan varian sebesar 153,2. Selanjutnya diperoleh $\quad \mathrm{T}_{\text {hitung }}>\mathrm{T}_{\text {tabel }} \quad$ yaitu 2,33>1,67 sehingga $\mathrm{H}_{0}$ ditolak $\mathrm{H}_{1}$ diterima dengan demikian terdapat pengaruh artinya strategi genius learning terhadap kemampuan berpikir kreatif peserta didik kelas $\mathrm{X}$ IPA SMA.

\section{DAFTAR PUSTAKA}

Alatas, F. (2014). Hubungan Pemahaman Konsep Dengan Keterampilan Berpikir Kritis Melalui Model Pembelajaran Treffinger Pada Mata Kuliah Fisika Dasar. Jurnal Edusains, 6(1).

Anita, R. P. (2016). Pengaruh Penerapan Genius Learning Strategy Tarhadap Hasil Belajar Siswa Pada Mata Pelajaran Ti\&K. E-Tech, 1(1).
Budiarti, Y. (2016). Pengaruh Metode Pembelajaran Creative Problem Solving (CPS) Terhadap Kemampuan Berpikir Kreatif Mahasiswa (Studi Eksperimen Pada Mahasiswa Pendidikan Ekonomi Fkip Um Metro). Jurnal Pendidikan Ekonomi Um Metro, 4(2).

Febrina Sari, R., Niniwati, \& Zuzano, F. (2017). Penerapan Model Treffinger Pada Pembelajaran Matematika Dalam Mengembangkan Kemampuan Kreatif Matematika Siswa Kelas Viii Smpn 12 Padang. Xlii (May), 1. Https://Doi.Org/10.5194/IsprsArchives-Xlii-5-W1-175-2017

Hendrayana, S. (2017). Meningkatkan Keterampilan Berpikir Rasional Siswa Melalui Model Sains Teknologi Masyarakat Pada Konsep Sumber Daya Alam. Jurnal Ilmiah Pendidikan Dasar, 2(1).

Istiyono, E., Bram Dwandaru, W., \& Rahayu, F. (2018). Pengembangan Tes Creative Thinking Skills Fisika Sma (Physcrethots) Berdasarkan Teori Tes Modern. Cakrawala Pendidikan, (2).

Maghfiroh, A. F., Djoko, A. L., \& Supriadi, B. (2017). Pengaruh Model Problem-Based Learning (PBL) Disertai Media Tiga Dimensi Terhadap Kemampuan Berpikir Kreatif Siswa Dan Hasil Belajar Siswa Dalam Pembelajaran Fisika Di Sma Negeri 4 Jember. Jurnal Pembelajaran Fisika, 6(1). 
Mawarni, \& Angraini, S. (2015). Efektivitas Model Pembelajaran Sinektiks Terhadap Kemampuan Berpikir Kreatif Dan Eksplorasi Peserta Didik. Jurnal Pendidikan Fisika, 3(1).

Meici, D., Rasmiwetti, \& Herdini. (2016). Penerapan Strategi Genius Learning Untuk Pokok Bahasan Koloid Di Kelas Xi Sma Negeri 2 Siak Hulu. Program Studi Pendidikan Kimia.

Naimah, K., \& A, M. (2017). Penerapan Metode Genius Learning Terhadap Hasil Belajar Siswa Pada Mata Pelajaran Sejarah Kebudayaan Islam Di Min 1 Teladan Palembang. Jurnal Radenfatah, 3(1).

Nilawati, M. (2016). Penerapan Strategi Genius Learning Untuk Meningkatkan Hasil Belajar Matematika Siswa Di Kelas Vii Mts. Muhammadiyah Sei Apung Jaya Kecamatan Tanjung Balai Kabupaten Asahan Tahun Pelajaran 2014/2015. Axiom, 5(1).
Pratiwi, M. N., Matematika, M. P., \& Dahlan, U. A. (2018). Analisis Kebutuhan Bahan Ajar Matematika Untuk Meningkatkan Berpikir Kritis Dan Kreatif Siswa.

Sari, I. M., Sumiati, E., \& Siahaan, P. (2013). Analisis Kemampuan Berpikir Kreatif Siswa Smp Dalam Pembelajaran Pembelajaran Pendidikan Teknologi Dasar (Ptd). Jurnal Pengajaran Mipa, 18(1).

Sari, W. P., Hidayat, A., \& Kusairi, S. (2018). Keterampilan Berpikir Kreatif Siswa Sma Dalam Pembelajaran Project Based Learning (PjBL) Pada Materi Fluida Statis. Jurnal Pendidikan, 3(6).

Winarti. (2015). Xtual Teaching And Learning (CTL) Untuk Meningkatkan Kemampuan Berpikir Kreatif Siswa. Jpfk, 1(1).

Yuberti. (2015). Peran Teknologi Pendidikan Islam. Akademika, 20(1). 